\title{
Laboratory Preparation of Hanford Waste Treatment Plant Direct Feed Low Activity Waste Off-Gas Condensate Simulant
}

Charles A. Nash

Kathryn M. Taylor-Pashow

Daniel J. McCabe

December, 2014

SRNL-STI-2014-00602, Revision 0 


\section{DISCLAIMER}

This work was prepared under an agreement with and funded by the U.S. Government. Neither the U.S. Government or its employees, nor any of its contractors, subcontractors or their employees, makes any express or implied:

1. warranty or assumes any legal liability for the accuracy, completeness, or for the use or results of such use of any information, product, or process disclosed; or

2. representation that such use or results of such use would not infringe privately owned rights; or

3. endorsement or recommendation of any specifically identified commercial product, process, or service.

Any views and opinions of authors expressed in this work do not necessarily state or reflect those of the United States Government, or its contractors, or subcontractors.

\section{Printed in the United States of America \\ Prepared for U.S. Department of Energy}


Keywords: Decontamination

Technetium

Strontium

Actinides

Cesium

Retention: Permanent

\section{Laboratory Preparation of Hanford Waste Treatment Plant Direct Feed Low Activity Waste Off-Gas Condensate Simulant}

Charles A. Nash

Kathryn M. Taylor-Pashow

Daniel J. McCabe

December 2014

Prepared for the U.S. Department of Energy under 


\section{REVIEWS AND APPROVALS}

\section{AUTHORS:}

Charles A. Nash, Advanced Characterization \& Process Research

Date

Kathryn M. Taylor-Pashow, Separation and Actinide Science

Date

Daniel J. McCabe, Advanced Characterization \& Process Research

Date

TECHNICAL REVIEW:

W. D. King, Advanced Characterization \& Process Research, Reviewed per E7 2.60 Date

APPROVAL:

F. M. Pennebaker, Manager

Date

Advanced Characterization and Process Research

C. C. Herman, Hanford Programs, Manager

Date

Environmental \& Chemical Process Technology Research Programs

D.J. Swanberg, Manager

Date

Washington River Protection Solutions

S. L. Marra, Manager

Date

Environmental \& Chemical Process Research Programs 


\section{EXECUTIVE SUMMARY}

The Hanford Waste Treatment and Immobilization Plant (WTP) Low Activity Waste (LAW) vitrification facility will generate an aqueous condensate recycle stream (LAW Off-Gas Condensate) from the off-gas system. The baseline plan for disposition of this stream is to send it to the WTP Pretreatment Facility, where it will be blended with LAW, concentrated by evaporation and recycled to the LAW vitrification facility again. An alternate start-up scenario that is under evaluation is to decontaminate tank waste in another facility, called the LAW Pretreatment System, and send the LAW directly to the LAW melters in WTP without starting up the Pretreatment Facility. This "Direct Feed LAW" (DFLAW) scenario will have a different chemical and radionuclide composition, and thus will have a different Off-Gas condensate composition. To examine the options for disposal of this stream, a simulant is needed for testing.

This LAW Off-Gas Condensate stream contains components that are volatile at melter temperatures and are problematic for incorporating into the glass waste form. Under the DFLAW scenario where the LAW vitrification facility commences operation prior to the WTP Pretreatment facility, identifying a disposition path becomes vitally important. This report describes the preparation and characterization of a simulant that can be used to examine the potential treatment of this stream to remove radionuclides for subsequent disposition. Options being considered include sending the decontaminated stream to the Effluent Treatment Facility (ETF), for example.

The origin of this LAW Off-Gas Condensate stream will be the liquids from the Submerged Bed Scrubber (SBS) and the Wet Electrostatic Precipitator (WESP) from the LAW melter off-gas system. The stream is expected to be a dilute salt solution with near neutral $\mathrm{pH}$, and will likely contain some insoluble solids from melter carryover. The soluble components are expected to be mostly sodium and ammonium salts of nitrate, chloride, and fluoride. This stream has not been generated yet and will not be available until the WTP begins operation, but a simulant has been produced based on models, calculations, and comparison with pilot-scale tests.

One of the radionuclides that is volatile and expected to be in greatest abundance in this LAW Off-Gas Condensate stream is Technetium-99 $\left({ }^{99} \mathrm{Tc}\right)$. Technetium will not be removed from the aqueous waste in the baseline Hanford WTP process, and will primarily end up immobilized in the LAW glass by repeated recycle of the off-gas condensate into the LAW melter during full WTP operations. Other radionuclides are projected by the model to be present at low concentrations that exceed the ETF acceptance criteria including ${ }^{129} \mathrm{I},{ }^{90} \mathrm{Sr},{ }^{137} \mathrm{Cs},{ }^{241} \mathrm{Pu}$, and ${ }^{241} \mathrm{Am}$. These are present due to their partial volatility and some entrainment in the off-gas system. 


\section{TABLE OF CONTENTS}

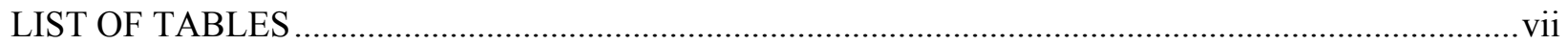

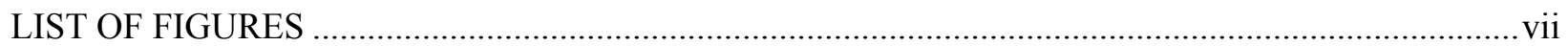

LIST OF ACRONYMNS and ABBREVIATIONS.........................................................................ii

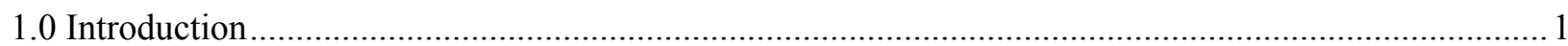

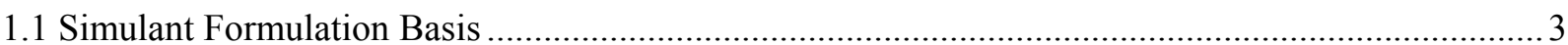

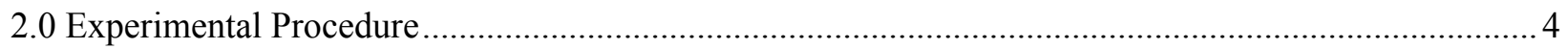

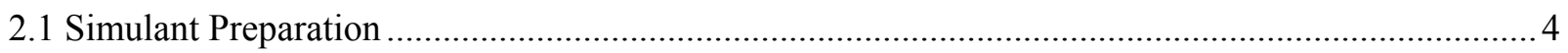

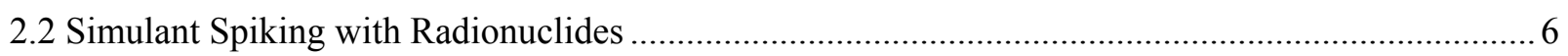

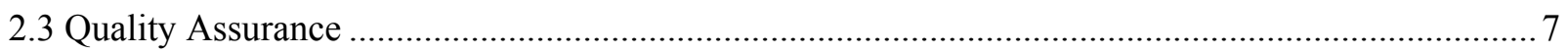

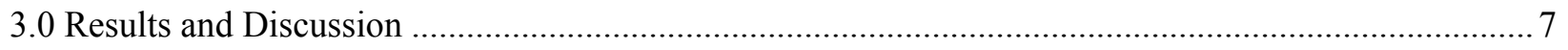

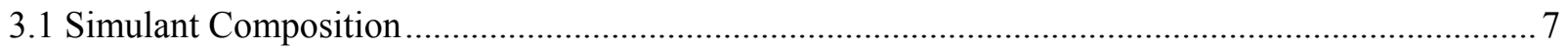

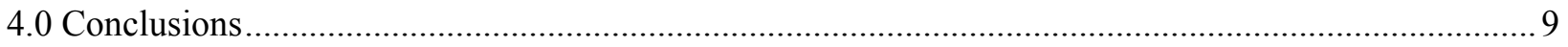

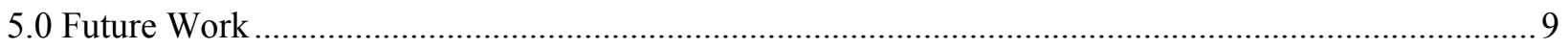

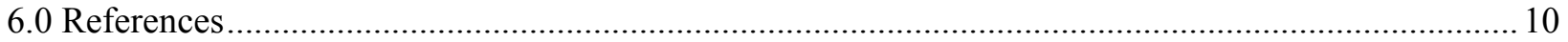




\section{LIST OF TABLES}

Table 2-1. Direct Feed LAW Off-gas Condensate Recycle Aqueous Phase Target Composition Based on SVF-3002, Rev. 1 and Adjusted.....

Table 2-2 Aqueous Simulant Formulation Targets and Actual …....................................................... 5

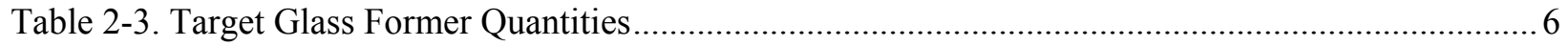

Table 2-4. Radiotracer Solutions added to Simulant ......................................................................... 6

Table 3-1 Neutralized Simulant Filtrate Chemical Composition............................................................... 8

Table 3-2. Average Simulant Control Sample Radionuclide Composition ............................................. 9

\section{LIST OF FIGURES}

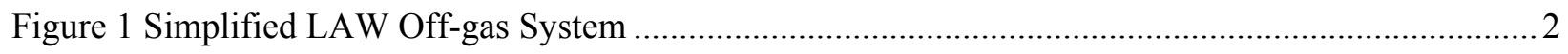




\section{LIST OF ACRONYMNS and ABBREVIATIONS}

\begin{tabular}{ll} 
Avg & Average \\
dpm & Disintegrations per minute \\
ETF & Effluent Treatment Facility \\
g & gram \\
h & hour \\
HLW & High-Level Waste \\
HTWOS & Hanford Tank Waste Operations Simulator \\
ICP-ES & Inductively Coupled Plasma - Emission Spectroscopy \\
ICP-MS & Inductively Coupled Plasma - Mass Spectrometry \\
IDF & Integrated Disposal Facility \\
L & Liter \\
LAW & Low-Activity Waste \\
LERF & Liquid Effluent Retention Facility \\
mg & milligram \\
mL & milliliter \\
PA & Performance Assessment \\
SBS & Submerged Bed Scrubber \\
SRNL & Savannah River National Laboratory \\
SRS & Savannah River Site \\
$\mu$ g & micrograms \\
WESP & Wet Electrostatic Precipitator \\
WG & Weapons Grade \\
WTP & Waste Treatment Plant \\
& \\
\hline &
\end{tabular}




\subsection{Introduction}

The Hanford LAW Off-Gas Condensate stream will be generated in the WTP by condensation and scrubbing of the LAW melter off-gas system by a SBS and WESP, as shown in Figure 1. In the baseline WTP processing flowsheet, this stream, which will contain substantial amounts of chloride, fluoride, ammonia, and sulfate ions, will get recycled within the WTP baseline process by return to the Pretreatment Facility where it will be combined with LAW and evaporated. The halide and sulfate components are only marginally soluble in glass, and can dictate the waste loading and thereby impact LAW waste glass volume. Additionally, long-lived ${ }^{99} \mathrm{Tc}$ and ${ }^{129} \mathrm{I}$ are volatile radionuclides that accumulate in the LAW system, and are challenging to incorporate in glass under the Hanford LAW melter operating conditions. Because ${ }^{99}$ Tc has a very long half-life and is highly mobile, it is the largest dose contributor to the Performance Assessment (PA) of the Integrated Disposal Facility (IDF) [Mann, 2003], although the glass waste form has been shown to meet the leaching requirements of the IDF waste acceptance criteria. Diverting this LAW Off-Gas Condensate stream to an alternate disposal path would have substantial beneficial impacts on the cost, life cycle, and operational complexity of WTP. Modeling calculations indicate that diverting this stream decreases the quantity of LAW glass canisters by over 43,000 and ends the mission nearly three years earlier [Arakali, 2012].

An alternate potential scenario is under evaluation where tank supernate is decontaminated in another facility, called LAW Pretreatment System, and sent directly to the LAW melter (a.k.a. Direct Feed LAW or DFLAW) without start-up of the Pretreatment Facility. In the DFLAW scenario, the offgas condensate stream would be returned to the Tank Farm after handling in the proposed Effluent Management Facility (EMF). The DFLAW scenario would require alternate disposal of this stream because the Pretreatment Facility would not be available. Further, this stream will potentially have a different chemical and radionuclide composition from the baseline projection, and thus will have a different Off-Gas condensate composition. To examine the options for disposal of this stream, a simulant is needed for testing.

This report describes the preparation and characterization of a simulant of the Off-gas Condensate stream that would be generated during DFLAW operations so that future testing can evaluate disposition options. 
Figure 1 Simplified LAW Off-gas System

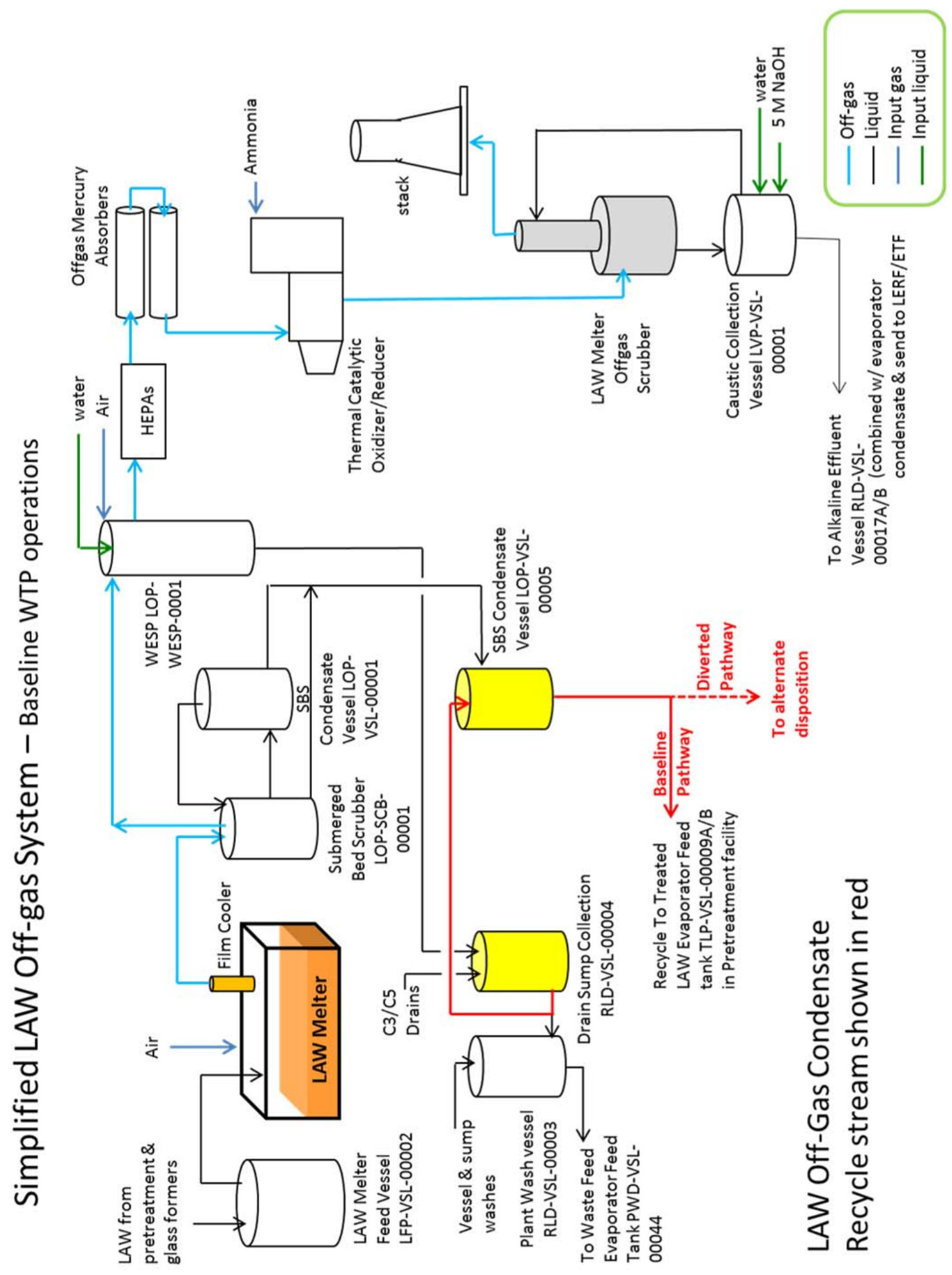

(adapted from 24590-WTP-RPT-PT-02-005, Rev. 6); (yellow indicates SBS/WESP LAW Off-Gas Condensate collection tanks, red lines indicate the collected off-gas condensate pathway) 


\subsection{Simulant Formulation Basis}

No melter demonstrations have been performed with the DFLAW processing scenario. Therefore, the condensate stream composition is not yet available, the simulant formulation was based on input from two sources. The projected solution chemistry and radionuclide content was based on version 7.4 of the Hanford Tank Waste Operations Simulator (HTWOS) modeling of the flow sheet [Belsher, 2012] performed by WRPS [SVF-3002, Rev. 1]. Prior work has used similar methodology to develop a comparable simulant [Adamson, 2013]. This model run was for the average composition of this stream for the DFLAW mission. Diversion of the Off-gas Condensate, rather than recycling, has the beneficial effect of decreasing the LAW melter feed concentrations of ${ }^{99} \mathrm{Tc},{ }^{129} \mathrm{I}, \mathrm{Cl}^{-}, \mathrm{F}^{-}$, and $\mathrm{SO}_{4}^{-}$because they do not continue to recycle and accumulate. Insoluble solids composition in the simulant was primarily based on analysis of LAW Off-Gas Condensate obtained from pilot-scale simulant melter testing [Matlack, 2006]. Basing the solution chemistry and radionuclide content on the computer modeling rather than melter testing results extends the range of compositions and allowed evaluation of process conditions for treatment of the selected tank wastes. Since the computer model does not account for carryover of solids by physical entrainment, the insoluble solids were based on results from pilot-scale melter off-gas system testing. Those results showed that the insoluble solids were high in iron, indicating that they are largely glassformers. Therefore, glass formers were added to the aqueous phase as the insoluble solid phase, where they react and either remain unreacted, dissolve, or cause precipitation of other species. Adding the glass formers to the aqueous phase in this way is an attempt to mimic the expected conditions in the off-gas system. Earlier simulant formulations also used this approach, and benchmarked the quantity of solids on boron concentration since it is essentially absent from LAW, highly soluble, and easy to analyze. Using boron is conservative because it is also more volatile than most other glass formers, and therefore preferentially partitions to the condensate stream. The glass formers are then filtered out to prevent their further reaction or sorption of the radionuclides which would otherwise convolute the test results. The HTWOS model run scenario used as the basis for the solution chemistry was the DFLAW operation using feed from several Double Shell Tanks (DSTs).

Although the formulation for synthesis of the simulant is based on HTWOS modeling, the model is not constrained to be charge neutral. In order to generate an actual simulant recipe, adjustments were required in order to obtain a charge neutral composition. In this case, only the sodium and nitrate salt concentrations are adjusted by roughly the same amount in opposite directions, i.e., the projected sodium cation content was $50 \%$ in excess of the anions, so it was decreased by $25 \%$, and the nitrate salts were increased by $25 \%$. The nitrate ion is then further allowed to vary by using nitric acid to adjust the $\mathrm{pH}$. (Ammonia, nitrate, and nitrite are present in this stream due to the destruction of nitrate by reaction with sucrose in the melter, generating ammonia and NOx, which are scrubbed out in the WESP and condense into the aqueous phase. Sucrose is added to the LAW 
melter feed to destroy the nitrate/nitrite and is expected to convert completely to carbon dioxide, which passes through the SBS/WESP scrubbers. )

The radionuclide contents in the DFLAW Off-gas Condensate Recycle were based on the HTWOS model run by WRPS [SVF-3002, Rev. 1]. For most radionuclides, a small fraction of each is volatile and captured in the off-gas scrubbers. Some fraction is also carried over by entrainment in the air sweep and bubbling in the LAW melter. Radionuclides selected for inclusion were based on a comparison to the Liquid Effluent Retention Facility (LERF)/ETF limits [McCabe, 2013]. Radionuclides that exceeded the limits were included, except for ${ }^{129} \mathrm{I}$ and ${ }^{151} \mathrm{Sm}$. The ${ }^{129} \mathrm{I}$ was excluded because current aqueous separation technologies are expected to be overwhelmed by the high halide concentrations, and because the ETF is currently equipped to handle some ${ }^{129}$ I. Furthermore, since one potential disposition path of the contaminated solids is vitrification, the ${ }^{129} \mathrm{I}$ would vaporize again in the melter, so a more comprehensive evaluation of its fate is needed. The ${ }^{151} \mathrm{Sm}$ was excluded because its calculated quantity is not credible and not expected to actually be present. It is also not appreciably soluble in LAW, based on comparison with SRS waste samples, and would be filtered in High Level Waste (HLW) and not be present in the LAW or LAW Off-Gas Condensate streams.

The decontamination process testing will be documented in a future report.

\subsection{Experimental Procedure}

\subsection{Simulant Preparation}

The target concentrations of chemicals and radionuclides were derived from the output from the HTWOS calculation, documented in SVF-3002, Rev. 1 and shown in Table 2-1. The aqueous phase was prepared from dissolution of laboratory chemicals, as shown in Table 2-2. A single batch of $1.0 \mathrm{~L}$ of simulant was prepared, spiked, and analyzed. The formulation adjusts the sodium and nitrate concentrations. Because the HTWOS model is not constrained to generate a charge-balanced composition, no formulation can match all component concentrations simultaneously, and the chemical formulation must balance between cations and anions to create a mixture that can actually be prepared. Minor adjustments $(5 \%)$ were made to some components versus the targets to account for this and to use readily available chemicals, and sodium and nitrate were adjusted by $25 \%$. Note that the information in Table 2-2 does not necessarily reflect the final composition of the aqueous phase because it is impacted by precipitation and reaction with the glass formers, and with the nitric acid added during $\mathrm{pH}$ adjustment. Also, the ${ }^{239} \mathrm{Pu}$ and ${ }^{241} \mathrm{Am}$ target concentrations were increased in an effort to raise the concentration high enough to be well above the analytical detection limit. Details of the chemical preparation of the simulant are in the attachment. 
Table 2-1. Direct Feed LAW Off-gas Condensate Recycle Aqueous Phase Target Composition Based on SVF-3002, Rev. 1 and Adjusted

\begin{tabular}{|l|l|l|}
\hline Constituent & $\begin{array}{l}\text { Calculated } \\
\text { Molarity }\end{array}$ & $\begin{array}{l}\text { Adjusted } \\
\text { Molarity* }\end{array}$ \\
\hline $\mathrm{Na}^{+}$ & 0.16 & 0.121 \\
\hline $\mathrm{K}^{+}$ & 0.0061 & \\
\hline $\mathrm{Al}^{+3}$ & 0.00032 & \\
\hline $\mathrm{Cl}^{-}$ & 0.041 & \\
\hline $\mathrm{F}^{-}$ & 0.029 & \\
\hline $\mathrm{SO}_{4}{ }^{-2}$ & 0.014 & \\
\hline $\mathrm{PO}_{4}^{-2}$ & 0.0005 & \\
\hline $\mathrm{NO}_{2}{ }^{-}$ & 0.0001 & \\
\hline $\mathrm{NO}_{3}{ }^{+}$ & 0.075 & 0.0932 \\
\hline $\mathrm{NH}_{4}{ }^{-2}$ & 0.062 & \\
\hline $\mathrm{CrO}_{4}{ }^{-2}$ & 0.00058 & \\
\hline $\mathrm{Isotope}^{137} \mathrm{Cs}$ & $\mathrm{Ci} / \mathrm{L}$ & \\
\hline${ }^{238} \mathrm{U}$ & $5.06 \mathrm{E}-6$ & \\
\hline${ }^{239 / 240} \mathrm{Pu}$ & $3.87 \mathrm{E}-11$ & \\
\hline${ }^{90} \mathrm{Sr}$ & $1.06 \mathrm{E}-8$ & \\
\hline${ }^{99} \mathrm{Tc}$ & $1.16 \mathrm{E}-6$ & $2.32 \mathrm{E}-7$ \\
\hline${ }^{241} \mathrm{Am}$ & $1.03 \mathrm{E}-4$ & \\
\hline
\end{tabular}

${ }^{*} \mathrm{Na}^{+}$and $\mathrm{NO}_{3}{ }^{-}$were adjusted from the SVF-3002 targets to achieve charge balance; $\mathrm{Pu}$ and $\mathrm{Am}$ were adjusted to permit analysis

Table 2-2 Aqueous Simulant Formulation Targets and Actual

\begin{tabular}{|l|l|c|c|}
\hline \multicolumn{1}{|c|}{ Chemical } & \multicolumn{1}{|c|}{ Formula } & $\begin{array}{c}\text { Target Mass } \\
\text { (g)/L } \\
\text { simulant }\end{array}$ & $\begin{array}{c}\text { Actual } \\
\text { Mass (g)/L } \\
\text { Added }\end{array}$ \\
\hline $\begin{array}{l}\text { Aluminum nitrate } \\
\text { nonahydrate }\end{array}$ & $\mathrm{Al}_{\left(\mathrm{NO}_{3}\right)_{3} \cdot 9 \mathrm{H}_{2} \mathrm{O}}$ & 0.12 & 0.1203 \\
\hline Sodium chromate & $\mathrm{Na}_{2} \mathrm{CrO}_{4}$ & 0.093 & 0.0934 \\
\hline Potassium chloride & $\mathrm{KCl}$ & 0.456 & 0.4563 \\
\hline Sodium chloride & $\mathrm{NaCl}$ & 2.05 & 2.0506 \\
\hline Sodium fluoride & $\mathrm{NaF}_{4}$ & 1.23 & 1.2302 \\
\hline Ammonium nitrate & $\mathrm{NH}_{4} \mathrm{NO}_{3}$ & 3.05 & 3.0520 \\
\hline Sodium nitrate & $\mathrm{NaNO}_{3}$ & 4.6 & 4.6031 \\
\hline Sodium nitrite & $\mathrm{NaNO}_{2}$ & 0.0094 & 0.0097 \\
\hline Ammonium sulfate & $\left(\mathrm{NH}_{4}\right)_{2} \mathrm{SO}_{4}$ & 1.8 & 1.8021 \\
\hline $\begin{array}{l}\text { Dibasic sodium } \\
\text { phosphate } \\
\text { dihydrate }\end{array}$ & $\mathrm{Na}_{2} \mathrm{HPO}_{4} 2 \mathrm{H}_{2} \mathrm{O}$ & 0.086 & 0.0864 \\
\hline
\end{tabular}


The glass formers were then added as shown in Table 2-3. These were derived from the overall mission average quantity [Arakali, 2012]. Sucrose was excluded because it is destroyed in the melter. The slurry was mixed for four days at ambient temperature of $23{ }^{\circ} \mathrm{C}$. After mixing, the solution was adjusted to be within the $\mathrm{pH}$ range of 7.0-7.5 with $20.2953 \mathrm{~g}$ of $0.18 \mathrm{M}$ nitric acid, mixed for over one hour, and then filtered with a 0.45 $\mu \mathrm{m}$ Nalgene ${ }^{\circledR 1}$ filter.

Table 2-3. Target Glass Former Quantities

\begin{tabular}{|c|c|c|c|}
\hline Mineral & Formula & $\begin{array}{c}\text { Target } \\
\text { Mass (g)/L } \\
\text { simulant }\end{array}$ & $\begin{array}{c}\text { Actual } \\
\text { Mass (g)/L } \\
\text { simulant } \\
\end{array}$ \\
\hline Kyanite & $\mathrm{Al}_{2} \mathrm{SiO}_{5}$ & 0.745 & 0.7453 \\
\hline Borax & $\mathrm{Na}_{2} \mathrm{~B}_{4} \mathrm{O}_{7} \cdot 10 \mathrm{H}_{2} \mathrm{O}$ & 0.0123 & 0.0125 \\
\hline Boric acid & $\mathrm{H}_{3} \mathrm{BO}_{3}$ & 1.430 & 1.4300 \\
\hline Wollastonite & $\mathrm{CaSiO}_{3}$ & 0.772 & 0.7727 \\
\hline Iron oxide (hematite) & $\mathrm{Fe}_{2} \mathrm{O}_{3}$ & 0.430 & 0.4306 \\
\hline Lithium carbonate & $\mathrm{Li}_{2} \mathrm{CO}_{3}$ & 0.392 & 0.3920 \\
\hline Forsterite olivine & $\mathrm{Mg}_{2} \mathrm{SiO}_{4}-\mathrm{Fe}_{2} \mathrm{SiO}_{4}$ & 0.257 & 0.2576 \\
\hline Sodium carbonate & $\mathrm{Na}_{2} \mathrm{CO}_{3}$ & 0.003 & 0.0031 \\
\hline Silica & $\mathrm{SiO}_{2}$ & 2.857 & 2.8570 \\
\hline Rutile & $\mathrm{TiO}_{2}$ & 0.114 & 0.1138 \\
\hline Zinc oxide & $\mathrm{ZnO}$ & 0.286 & 0.2866 \\
\hline Zircon & $\mathrm{ZrSiO}_{4}$ & 0.372 & 0.3723 \\
\hline Sucrose & $\mathrm{C}_{12} \mathrm{H}_{22} \mathrm{O}_{11}$ & 0 & 0 \\
\hline & Total & 7.67 & 7.6741 \\
\hline
\end{tabular}

The filtrate was then spiked with the radioisotope tracers. Samples were analyzed for elemental composition by Inductively Coupled Plasma - Emission Spectroscopy (ICPES), anions and ammonium by Ion Chromatography.

\subsection{Simulant Spiking with Radionuclides}

The filtrate was spiked with the radiotracer solutions shown in Table 2-4.

Table 2-4. Radiotracer Solutions added to Simulant

\begin{tabular}{||c|l|c||}
\hline Isotope & \multicolumn{1}{|c|}{ Matrix } & $\begin{array}{c}\text { Target } \\
\text { concentration } \\
\text { (dpm/mL) }\end{array}$ \\
\hline${ }^{137} \mathrm{Cs}$ & ${ }^{137} \mathrm{Cs}$ in $0.1 \mathrm{M} \mathrm{HCl}$ & $1.12 \mathrm{E} 4$ \\
\hline${ }^{238} \mathrm{U}$ & $\mathrm{UO}_{2}\left(\mathrm{NO}_{3}\right)_{2} 6 \mathrm{H}_{2} \mathrm{O}$ solid & $8.59 \mathrm{E}-2$ \\
\hline${ }^{239 / 240} \mathrm{Pu}$ & $1.5 \mathrm{~g} / \mathrm{L} \mathrm{WG} \mathrm{Pu}$ in $0.45 \mathrm{M} \mathrm{HNO}$ & $8.42 \mathrm{E} 1$ \\
\hline${ }^{85} \mathrm{Sr}$ & ${ }^{85} \mathrm{Sr}$ radionuclide in $0.5 \mathrm{M} \mathrm{HCl}$ & $2.58 \mathrm{E} 3 *$ \\
\hline${ }^{99} \mathrm{Tc}$ & Ammonium pertechnetate solution & $2.29 \mathrm{E} 5$ \\
\hline${ }^{241} \mathrm{Am}$ & ${ }^{241} \mathrm{Am}$ aqueous stock solution & $5.15 \mathrm{E} 2$ \\
\hline
\end{tabular}

*2.58E3 dpm/mL is the target for ${ }^{90} \mathrm{Sr}$, but ${ }^{85} \mathrm{Sr}$ was used to allow for easier analysis

\footnotetext{
${ }^{1}$ Nalgene is a registered trademark of the Nalge Company Corporation, Rochester, New York.
} 
After stirring for at least 3 hours, the batch was filtered with a $0.45-\mu \mathrm{m}$ Nalgene ${ }^{\circledR}$ filter. The filtrate was then analyzed for radionuclide contents. Analysis methods utilized Inductively Coupled Plasma - Mass Spectroscopy (ICP-MS) (for ${ }^{99} \mathrm{Tc}$ and ${ }^{238} \mathrm{U}$ ), gamma spectroscopy (for ${ }^{85} \mathrm{Sr},{ }^{137} \mathrm{Cs}$, and ${ }^{241} \mathrm{Am}$ ), and alpha pulse height analysis after an extraction with thenoyltrifluoroacetone (for ${ }^{239 / 240} \mathrm{Pu}$ ). Non-radioactive constituents were analyzed as described above. Results are summarized in Section 3.

\subsection{Quality Assurance}

This test program is described in the Task Technical and Quality Assurance Plan for Technetium Ion Exchange Resin Manufacturing Maturation [McCabe, 2014]. Requirements for performing reviews of technical reports and the extent of review are established in manual E7 2.60. Savannah River National Laboratory (SRNL) documents the extent and type of review using the SRNL Technical Report Design Checklist contained in WSRC-IM-2002-00011, Rev. 2.

\subsection{Results and Discussion}

\subsection{Simulant Composition}

Chemical analysis results of a sample of the neutralized and filtered simulant is shown in Table 3-1. The analyses match the target compositions reasonably well. Although boron, lithium, silicon, zinc, and carbonate were not in the aqueous simulant preparation, they are present in the solution due to addition of the glass former solids and their subsequent dissolution. It appears that all of the lithium carbonate and boric acid dissolved, but only a small amount of a silicon mineral and a small amount of the zinc oxide dissolved. Additionally, the analyzed soluble fluoride in the simulant was about $50 \mathrm{mg} / \mathrm{L}$ lower than the target, and the phosphate is much lower than the target. Presumably, both fluoride and phosphate precipitated from the solution. The target concentration for soluble aluminum was $8.7 \mathrm{mg} / \mathrm{L}$, based on computer modeling. However, consistent with prior results, the aluminum is not sufficiently soluble. 
Table 3-1 Neutralized Simulant Filtrate Chemical Composition

\begin{tabular}{|c|c|c|c|}
\hline Component & $\begin{array}{c}\text { DFLAW Simulant } \\
\text { Concentration } \\
(\mathrm{mg} / \mathrm{L})\end{array}$ & $\begin{array}{l}\text { Method } \\
\text { uncertainty } \\
\text { (\% RSD) }\end{array}$ & $\begin{array}{l}\text { HTWOS projection } \\
\text { Adjusted (avg. SVF-3002, R. } \\
\text { 1) (mg/L) }\end{array}$ \\
\hline $\mathrm{Al}$ & $<0.309$ & $\mathrm{~N} / \mathrm{A}$ & 8.7 \\
\hline $\mathrm{B}$ & 243 & 10 & $\mathrm{GF}^{1}$ (251 $\mathrm{mg}$ added as GF) \\
\hline $\mathrm{Ca}$ & 3.67 & 10 & $\mathrm{GF}^{1}$ (266 $\mathrm{mg}$ added as GF) \\
\hline $\mathrm{Cr}$ & 28.4 & 10 & 30 \\
\hline $\mathrm{Fe}$ & $<0.07$ & $\mathrm{~N} / \mathrm{A}$ & $\mathrm{GF}^{1}$ (385 $\mathrm{mg}$ added as GF) \\
\hline $\mathrm{K}$ & 242 & 10 & 239 \\
\hline $\mathrm{Li}$ & 72 & 10 & $\mathrm{GF}^{1}\left(73.6 \mathrm{mg}\right.$ added as $\left.\mathrm{Li}_{2} \mathrm{CO}_{3}\right)$ \\
\hline $\mathrm{Mg}$ & 1.01 & $\mathrm{~N} / \mathrm{A}$ & $\mathrm{GF}^{1}(36 \mathrm{mg}$ added as GF) \\
\hline $\mathrm{Na}$ & $2.66 \mathrm{E} 3$ & 10 & $2.78 \mathrm{E} 3$ \\
\hline $\mathrm{P}$ & 4.38 & 11.8 & 15 (added as $\left.\mathrm{PO}_{4}{ }^{-3}\right)$ \\
\hline $\mathrm{S}$ & 465 & 10.3 & 435 (added as $\left.\mathrm{SO}_{4}^{-2}\right)$ \\
\hline $\mathrm{Si}$ & 37.9 & 10 & $\mathrm{GF}^{1}(1752 \mathrm{mg}$ added as GF) \\
\hline $\mathrm{Ti}$ & $<0.047$ & $\mathrm{~N} / \mathrm{A}$ & $\mathrm{GF}^{1}(68 \mathrm{mg}$ added as GF $)$ \\
\hline $\mathrm{Zn}$ & 4.8 & 10 & $\mathrm{GF}^{1}$ (230 $\mathrm{mg}$ added as GF) \\
\hline $\mathrm{Zr}$ & $<0.031$ & $\mathrm{~N} / \mathrm{A}$ & $\mathrm{GF}^{1}$ (185 $\mathrm{mg}$ added as GF) \\
\hline $\mathrm{F}^{-}$ & 511 & 10 & 559 \\
\hline $\mathrm{Cl}^{-}$ & $1.45 \mathrm{E} 3$ & 10 & $1.46 \mathrm{E} 3$ \\
\hline $\mathrm{NO}_{2}^{-}$ & $<10$ & $\mathrm{~N} / \mathrm{A}$ & 6.3 \\
\hline $\mathrm{NO}_{3}^{-}$ & $5.90 \mathrm{E} 3$ & 10 & $5.78 \mathrm{E} 3$ \\
\hline $\mathrm{SO}_{4}^{-2}$ & $1.29 \mathrm{E} 3$ & 10 & $1.31 \mathrm{E} 3$ \\
\hline $\mathrm{PO}_{4}^{-3}$ & $<20$ & $\mathrm{~N} / \mathrm{A}$ & 46 \\
\hline $\mathrm{CO}_{3}{ }^{-2}$ & 319 (63.4 as TIC) & 10 & $\mathrm{GF}^{1}\left(318 \mathrm{mg}\right.$ added as $\left.\mathrm{Li}_{2} \mathrm{CO}_{3}\right)$ \\
\hline $\mathrm{NH}_{4}^{+}$ & $1.14 \mathrm{E} 3$ & $\mathrm{~N} / \mathrm{A}$ & $1.18 \mathrm{E} 3$ \\
\hline
\end{tabular}

${ }^{\mathrm{I}}$ Glass Former component; minimal HTWOS projected concentration

The filtered simulant was spiked with radioisotopes, and re-filtered prior to analysis. The $\mathrm{Cs}, \mathrm{U}$, and $\mathrm{Tc}$ were within the expected range. The $\mathrm{Pu}$ and $\mathrm{Am}$ were both well below the spike target, indicating they had very limited solubility in the simulant. The Sr was well in excess of the target, possibly due to dilution errors or subsample homogeneity issues because the spike had to be serially diluted to get within a range of liquid that could be manipulated in a pipette. This is considered acceptable because the absolute concentration of radioisotope is not relevant to the test objective, since a different isotope $\left({ }^{85} \mathrm{Sr}\right)$ is being used instead of the one present in the waste $\left({ }^{90} \mathrm{Sr}\right)$ anyway to enable better detection limits and easier analysis. 
Table 3-2. Average Simulant Control Sample Radionuclide Composition

\begin{tabular}{|l|l|c|c|}
\hline \multicolumn{1}{|c|}{ Isotope } & \multicolumn{1}{|c|}{ Concentration } & $\begin{array}{c}\text { Reported Method } \\
\text { Uncertainty }\end{array}$ & $\begin{array}{c}\text { \% of Target } \\
\text { Concentration }\end{array}$ \\
\hline${ }^{137} \mathrm{Cs}$ & $1.43 \mathrm{E} 4 \mathrm{dpm} / \mathrm{mL}$ & $5.0 \%$ & 127 \\
\hline${ }^{238} \mathrm{U}$ & $0.128 \mathrm{mg} / \mathrm{L}$ & $20 \%$ & 113 \\
\hline${ }^{239 / 240} \mathrm{Pu}$ & $7.17 \mathrm{dpm} / \mathrm{mL}$ & $42.8 \%$ & 8.5 \\
\hline${ }^{85} \mathrm{Sr}$ & $1.1 \mathrm{E} 4 \mathrm{dpm} / \mathrm{mL}$ & $5.0 \%$ & 427 \\
\hline${ }^{99} \mathrm{Tc}$ & $4.73 \mathrm{mg} / \mathrm{L}$ & $20 \%$ & 78 \\
\hline${ }^{241} \mathrm{Am}$ & $<17.8 \mathrm{dpm} / \mathrm{mL}$ & $\mathrm{mda}$ & $<3.5$ \\
\hline
\end{tabular}

mda = minimum detectable activity

\subsection{Conclusions}

A simulant formulation of the SBS-WESP Off-gas Condensate Recycle has been generated, and is within the expected composition range for chemical components. However, the Am and Pu have low solubility in the stream, so it may not be necessary to develop sorbents or methods to remove them. Simply filtering or settling the solution will likely be sufficient to achieve the decontamination factors.

Although this simulant formulation is within the range of compositions predicted by the HTWOS model, it should be noted that this model was not developed for the purpose of predicting the chemical composition of this stream. The model is not a chemical thermodynamics or kinetics-based program. Although useful, the projected composition should not be used for final design, regulatory, or safety-basis related calculations.

\subsection{Future Work}

This simulant can be used for additional testing on radionuclide removal, evaporation, or other processing related to this stream for DFLAW. 


\subsection{References}

Adamson, D.J., Nash, C.A., McCabe, D.J., Crawford, C.L., Laboratory Testing of Hanford Waste Treatment Plant Low Activity Waste Recycle Simulant, SRNL-STI2013-00713

Arakali, V., Stone, I., 2012 WTP Tank Utilization Assessment, 24590-WTP-RPT-PE-12-001, Rev. 0, March 26, 2012

Belsher, J.D., Empey, P.A., Hohl, T.M., Kirkbride, R.A., Ritari, J.S., West, E.B., Bergmann, L., M., Wells, M.N., Hanford Tank Waste Operations Simulator (HTWOS) Version 7.4 Model Design Document, RPP-17152, Rev. 7, November, 2012

Lueck, K.J., Mcnamar, E.A., Low Activity Waste (LAW) Facility Secondary Waste to Effluent Treatment Facility (ETF) Treatability Evaluation, HNF-37718, May, 2008

Mann, F.M., Puigh, R.J., Khaleel, R., Finfrock, S., McGrail, B.P., Bacon, D.H., Serne, R.J., Risk Assessment Supporting the Decision on the Initial Selection of Supplemental ILAW Technologies, RPP-17675, Rev. 0, September 29, 2003

Matlack, K.S., Gong, W., Diener, G., Bardakci, T., Brandys, M., Pegg, I.L., Final Report; Summary of DM1200 SBS History and Performance, VSL-066410-2, August 2, 2006

McCabe, D.J., Wilmarth, W.R., Nash, C.A., Waste Treatment Technology Process Development Plan for Hanford Waste Treatment Plant Low Activity Waste Recycle, SRNL-STI-2013-00351, July, 2013

McCabe, D.J., Task Technical and Quality Assurance Plan for Technetium Ion Exchange Resin Manufacturing Maturation, SRNL-RP-2012-00708, Rev. 3, August 7, 2014

Taylor-Pashow, K.M., Nash, C.A., Crawford, C.L., McCabe, D.J., Wilmarth W.R., Laboratory Scoping Tests of Decontamination of Hanford Waste Treatment Plant Low Activity Waste Off-Gas Condensate Simulant, SRNL-STI-2013-719, January, 2014 
SRNL-STI-2014-00602

Revision 0

\subsection{Attachment}

Chemical simulant preparation instructions

NOTE: These instructions do NOT include information about safety controls, personal protective equipment, or precautions needed to prevent chemical exposure 
Date:

Work Directions for Preparing Stock DFLAW SBS Simulant for Batch Work eHAP: SRNL-L3000-2009-00027, rev. 3

Set up a stir plate in a chemical hood, with a clean and dry 1-liter volumetric flask + lid that will hold 1 liter with mixing.

Label the volumetric flask:

\author{
DFLAW SBS Simulant with Glass Former \\ Researcher's name \\ Today's date \\ Hazards: RCRA metal (Cr)
}

Make sure the flask is clean and dry. Determine the tare/dry/empty weight of the flask/lid and record below. Also write the mass on the flask.

Empty Flask + Lid Mass:

Add a stir bar and $\sim 500 \mathrm{~g}$ of ASTM Type I (18 M.ohm.cm) water into the flask.

Commence gentle mixing in the order dictated below and weigh the soluble chemicals in the table below and add to the flask (use weigh boat to avoid overshooting the targets). All chemicals are anhydrous unless water of hydration in the formula is shown. Use ASTM-I water to rinse any chemical fines from the weigh boats into the carboy.

Continue mixing until all chemicals dissolve in the flask.

Balance M\&TE, expiration:

\begin{tabular}{|l|c|c|}
\hline Chemical & $\begin{array}{c}\text { Target } \\
\text { Mass, g }\end{array}$ & $\begin{array}{c}\text { Simulant \#1 } \\
\text { Actual Mass, g }\end{array}$ \\
\hline $\mathrm{NaF}$ (in hood) & 1.23 & \\
\hline $\mathrm{Al}(\mathrm{NO} 3) 3 * 9 \mathrm{H} 2 \mathrm{O}$ & 0.12 & \\
\hline $\mathrm{NaCl}$ & 2.05 & \\
\hline $\mathrm{KCl}$ & 0.456 & \\
\hline $\mathrm{Na} 2 \mathrm{CrO} 4$ (in hood) & 0.093 & \\
\hline $\mathrm{Na} 2 \mathrm{HPO} 4$ *H2O & 0.086 & \\
\hline $\mathrm{NaNO3}$ & 4.6 & \\
\hline NaNO2 & 0.0094 & \\
\hline $\begin{array}{l}\text { NH4NO3 } \\
(\text { potential ammonia } \\
\text { smell })\end{array}$ & 3.05 & \\
\hline $\begin{array}{l}(\text { NH4)2(SO4) } \\
(* 2 \mathrm{H} 2 \mathrm{O})\end{array}$ & $\begin{array}{c}1.8 \\
(2.3)\end{array}$ \\
\hline
\end{tabular}


In the original flask, continue mixing and add the glass formers as shown in the table below. These chemicals will NOT all dissolve into the solution. Use water as needed to get these materials into the flask. Hopefully the $\sim 400 \mathrm{~mL}$ margin above the original $500 \mathrm{~mL}$ will be enough to efficiently transfer all ingredients to the flask.

\begin{tabular}{|l|c|c|}
\hline Chemical & $\begin{array}{c}\text { Target } \\
\text { Mass, g }\end{array}$ & $\begin{array}{c}\text { Simulant \#1 } \\
\text { Actual Mass, g }\end{array}$ \\
\hline Kyanite & 0.745 & \\
\hline Borax & 0.0123 & \\
\hline Boric Acid & 1.43 & \\
\hline Wollastonite & 0.772 & \\
\hline Iron oxide (hematite) & 0.43 & \\
\hline $\begin{array}{l}\text { Lithium Carbonate (in } \\
\text { hood) }\end{array}$ & 0.392 & \\
\hline Foresterite Olivine & 0.257 & \\
\hline Sodium Carbonate & 0.003 & \\
\hline Fumed Silica (in hood) & 2.857 & \\
\hline Rutile & 0.114 & \\
\hline Zinc Oxide & 0.286 & \\
\hline Zircon & 0.372 & \\
\hline
\end{tabular}

After all the chemicals have been added and the flask has been stirred for $>1$ hour, remove the stir bar and fill with ASTM-I water to the final mark of $1000 \mathrm{~mL}$

Determine the final mass of the full (1L) flask and record below:

$1,000 \mathrm{~mL}=$ (Final Mass)

Add the stir bar and begin mixing

After 5 days of mixing, adjust the $\mathrm{pH}$ of the solution with the addition of $\mathrm{HNO} 3$ to $\mathrm{pH} 7.0-7.5$ :

Date/time:

Nitric acid Concentration:

Quantity:

Let solution stir for $>1$ hour

Filter the solution.

Date/time: 


\section{Distribution:}

S. L. Marra, 773-A

F. M. Pennebaker, 773-42A

T. B. Brown, 773-A

E. N. Hoffman, 999-W

D. H. McGuire, 999-W

S. D. Fink, 773-A

C. C. Herman, 773-A

K. M. L. Taylor-Pashow, 773-A

C. A. Nash, 773-42A

C. L. Crawford, 773-42A

D. J. McCabe, 773-42A

W. R. Wilmarth, 773-A

D. T. Herman, 735-11A

A. D. Cozzi, 999-W

D. K. Peeler, 999-W

K. M. Fox, 999-W

K. H. Subramanian, WRPS

Records Administration (EDWS)

J. A. Diediker. DOE-ORP

L. Holton, DOE-ORP

W. F. Hamel, DOE-ORP

T. W. Fletcher, DOE-ORP

S. H. Pfaff, DOE-ORP

S. T. Arm, WRPS

P. A. Cavanah, WRPS

T. W. Crawford, WRPS

W. G. Ramsey, WRPS

D. J. Swanberg, WRPS

N. P. Machara, DOE-EM

J. A. Poppiti, DOE-EM

D. J. Koutsandreas, DOE-EM

R. A. Gilbert, DOE-ORP

C. J. Winkler, WRPS

R. H. Spires, WRPS 